\title{
Monetary Agreements Reform and Issue of the Key Fiscal Convergence Criterion in the West African Economic and Monetary Union (WAEMU)
}

\author{
Léleng Kebalo ${ }^{1+}$ and Stéphane Zouri ${ }^{2}$ \\ ${ }^{1}$ University of Lomé, Togo \\ ${ }^{2}$ Central Bank of West African States, Senegal
}

\begin{abstract}
This paper estimates a fiscal deficit threshold that maximizes economic growth and is favorable to business cycles synchronization given the compliance of countries. The analysis covers the eight countries that form the West African Economic and Monetary Union (WAEMU) across 1990-2018. Our results show that $11.42 \%$ of the Gross Domestic Product (GDP) is the fiscal deficit threshold which should not to be exceeded and that fulfills the aforementioned conditions. Since the debt relief program in 2006, however, this threshold has been reduced from $11 \%$ to $3.97 \%$. Therefore, compliance with the key fiscal convergence criterion limiting the fiscal deficit to $3 \%$ of the GDP and in force in the Union is pro-growth and favorable to business cycles synchronization. However, even if this convergence criterion seems rigorous for fiscal discipline and can be maintained, it could be adjusted to $4 \%$. The paper discusses the advantages of this proposed adjustment.
\end{abstract}

Keywords: single currency, fiscal balance, business cycles synchronization, WAEMU

JEL Classifications: E32, E62, F45, O55

Received 9 April 2021, Revised 15 November 2021, Accepted 15 December 2021

\section{Introduction}

December 21, 2019 marked a major stride regarding the economic and monetary integration of West African Economic and Monetary Union's (WAEMU) eight member states. Dating back to 1962, WAEMU is one of the oldest sub-regional unions today. By laying the foundation of adopting the future currency named ECO — a single currency project for the sub-region - the Union has effectively reviewed the monetary cooperation agreements existing between France

+Corresponding Author: Léleng Kebalo

Ph.D., Research Associate at LEAMA, University of Lomé, 01BP1515, Togo. Email: kebalo.leleng@gmail.com, Orcid ID: 0000-0003-0108-8967

Co-Author: Stéphane Zouri

Ph.D., Economist, Central Bank of West African States, Senegal. Email: szouri@bceao.int

Acknowledgments: We are grateful to all participants of the 9th session of peer-to-peer research seminar series of the Africa Training Institute (ATI) and anonymous reviewers for their comments and suggestions.

Disclamer: The views expressed in the paper are those of the authors and do not necessarily reflect those of the University of Lomé and the Central Bank of West African States (BCEAO). 
and their member countries (BCEAO ${ }^{1)}$ Annual Report, 2019). The main features of this reform include, (1) the renaming of the current single currency CFA franc into ECO, leading up to the launch of the single currency of ECOWAS2); (2) end of centralization of exchange reserves at the French Treasury; (3) shutting down of the operating account and transfer into BCEAO accounts of resources that are currently available on the account; and (4) withdrawal of French representatives from the Union's decision-making and management institutions ${ }^{3)}$. However, WAEMU desires to retain two key pillars of the zone's monetary stability, i.e., the fixed exchange rate vis-a-vis the euro (which defines the current parity) and the currency's unlimited convertibility guarantee by France.

Despite these announced changes, the member countries commit to undertake reforms and steps to improve their Union's viability. Since a monetary union cannot be viable without a minimum of macroeconomic convergence, the member countries intend to reappraise the Growth and Convergence Pact from January 2015 (supplementary Act No. 1/2015/CCEG/WAEMU), which expired in 2019. The Growth and Convergence Pact 4 ) aims to facilitate the harmonization of economic policies within the Union, ensure the coordination of these policies, strengthen the convergence of the member countries' economies, support macroeconomic stability, and strengthen monetary cooperation, all of which are necessary in ensuring the viability of a union.

However, a new Growth and Convergence Pact has been in discussion since the end of December 2020. The decision was motivated by the region's economic situation, in the wake of the coronavirus disease 2019 (COVID-19), and took into consideration newer security challenges. This situation puts pressure on public finances through the combined effects of decreased fiscal resources and increased spending to deal with the situation, and required a reassessment of the viability of public finances.

This paper aims to provide empirical evidence on the need to revise or leave one of the important convergence criteria from the previous pact. The criterion is the key fiscal convergence criterion limiting the fiscal deficit, including grants, to 3\% of Gross Domestic Product (GDP). Based on Buti et al. (2001) and Kebalo and Zouri (2021), we believe that this criterion is the most indispensable to the economic convergence of countries, and compliance with it facilitates economic convergence and allows for increasing the level of fiscal discipline (Buti et al., 2001; Manasse, 2015), resilience capacity of the countries and the Union, while allowing the fiscal policy to support economic growth (Adam \& Bevan, 2005; Amadou \& Kebalo, 2019). Moreover,

1) Central Bank of West African States (BCEAO).

2) Economic Community of West African States (ECOWAS).

3) Board, Monetary Policy Committee of BCEAO, WAEMU Banking Commission.

4) There are five convergence criteria (5): both convergence criteria relate to wage bill ratios over fiscal income $\leq$ $35 \%$ fiscal income over nominal GDP $\geq 20 \%$. The three primary criteria are, among others: the average yearly inflation rate $\leq 3 \%$, the ratio of outstanding internal and external debt in proportion to nominal GDP $\leq 70 \%$, and the overall fiscal balance, including grants, ratio, in relation to nominal GDP $\geq-3 \%$. 
compliance contributes to the improvement of business cycles synchronization. According to Agnello et al. (2013, 2016), fiscal consolidation programs carried out simultaneously by various countries aids in closely aligning their business cycles.

We believe that introducing the fiscal convergence criterion within the Union contributes to improving business cycles synchronization through the harmonization of economic policies. Thus, without putting into question the validity of the 3\% GDP threshold as a fiscal convergence criterion, we believe this standard5) could be revised to better consider economic realities. That is why our approach initially consists, in determining endogenously, that the optimal fiscal deficit threshold should not be exceeded, so that the fiscal balance can have a positive effect on economic growth. Next, we analyze the business cycles synchronization effect of complying with the estimated threshold in the region. Then, in a third phase, we discuss the possibility of revising or leaving the key fiscal convergence criterion.

We substantially contribute to a sparse empirical literature on the analysis of the fiscal deficit threshold that is not to be exceed, for the fiscal policy to have a positive effect on economic growth. We justify compliance with the estimated threshold through the closer alignment of business cycles. Then, we use various estimators to carry out a robustness analysis. Finally, our analysis brings a response to a major economic and political issue regarding the future of WAEMU currency.

The analysis includes the eight WAEMU countries and covers the period from 1990 to 2018. Relying on Hansen (1999), we find that the fiscal deficit threshold that should not be exceeded to support economic growth is about $11.42 \%$ of the GDP and favorable to business cycles synchronization. However, since the start of debt relief programs in the Union in 2006, the fiscal deficit threshold that should not be exceeded was reduced to $3.97 \%$ of the GDP. Even though the key fiscal convergence criterion in force within the Union and present in the 2015 Convergence Pact seems more stringent regarding fiscal discipline and therefore, can be maintained, from our analysis, due to recent developments, it could be revised and adjusted to $4 \%$ of the GDP. Indeed, compliance with this proposal can significantly improve the level of business cycles synchronization. Additionally, within the current WAEMU context, the additional margin of $1 \%$ of the GDP could be used to increase economic financing, the fight against terrorism, economic transformation, human capital development, and the response against COVID-19. Such adjustments of the convergence criterion related to fiscal balance would contribute to strengthening the WAEMU zone's economic viability.

5) This standard which is derived from the Euro Zone Pact is quasi-replicated within WAEMU, is void of economic foundations. According to Guy Abeille, former Head of Mission at the French Ministry of Finances, this ratio is hazardously inspired by France. In 1981, when expenditure surges and with the prospect of a deficit reaching 100 billion French francs on the horizon, the team around François Mitterrand looks for a "red rag" to shake to impose rigor to his Socialist ministers. In relation to GDP forecasts for 1982, the 100 billion make up 3\% of the GDP. Although devoid from any economic rationale, in 1992 it is this $3 \%$ threshold which is applied by Europeans, and that will serve as the basis for calculation of the $60 \%$ rule regarding debt. 
The rest of the study is organized as follows. Section 2 presents a few stylized facts. Section 3 presents the methodological framework and data. Sections 4 and 5 present and discuss the results and the economic implications, respectively. Finally, Section 6 concludes the study.

\section{Stylized Facts}

Figures 1 and 2 illustrate the overall budget balances (including grants) of WAEMU and the Union's member countries from 1990 to 2018, respectively. These figures reveal that the countries, almost continuously, present public deficits. The phases of fiscal surplus are less frequent (Figure 1). Excluding the year 2006 when a fiscal surplus was recorded, the Union has had a continuous overall deficit fiscal balance since 1990. This can be explained by problems of resource mobilization (due to the high weight of the informal sector), high public expenditures, and tax evasion and avoidance. This low resource mobilization reflects a low tax pressure that rarely exceeds 20\% (Figure 3). During the 2015 Growth and Convergence Pact, to encourage countries to raise more tax revenue, a second-order convergence criterion was introduced that required countries to have a tax pressure (tax revenue in \% of the GDP) above $20 \%$.

Second, it appears that the countries are characterized by a weak culture of fiscal discipline (Figures 1 and 2). The WAEMU countries have difficulty complying with the key fiscal convergence criterion limiting the fiscal deficit to $3 \%$ of the GDP, which belong to the 2015 Convergence Pact (Diarra, 2016). This criterion was introduced to allow countries to be more fiscally disciplined (to contain debt to be more sustainable), and to allow them to have legroom to maneuver and finance their economic activities (Diarra, 2016). The establishment within a union and the respect by member countries of a convergence criterion limiting the fiscal deficit contribution to improving fiscal discipline, supporting economic growth and facilitating economic convergence (Amadou \& Kebalo, 2019; Buti et al., 2001; Kebalo \& Zouri, 2021). In 2018, only Benin (-2.98) and Togo $(-0.78)$ met the key fiscal convergence criterion out of all WAEMU member countries. These countries benefited from the International Monetary Fund (IMF) program supported by the Extended Credit Facility to consolidate their fiscal positions. Niger (-3.05) and Senegal (-3.62) made efforts to move closer to the standard.

Third, Figures 1 and 2 show a break in the evolution of the overall fiscal balance over time in the Union where we can distinguish two different phases (1990-2005 and 2006-2018, respectively). The first phase is marked by a gradual reduction in the fiscal deficit while the second is a gradual deterioration in the fiscal balance despite the introduction of the key fiscal convergence criterion limiting fiscal deficit. During the first phase, the average fiscal deficit was about $3.43 \%$ of the GDP while it was about $2.63 \%$ during the second phase.

The break in the trend in the fiscal balance in 2006 is due to the introduction of debt relief 
programs (initiative for highly indebted countries) in the Union from 2006 (Figure 4). It is explained by the opportunity cost of the debt relief programs since 2006. Before 2006, countries had to consolidate their fiscal positions to be eligible and benefit from the debt reduction program. With an average debt in the Union approaching 108\% of the GDP before 2006 (Figure 4), countries made fiscal consolidation efforts and therefore gradually contained their fiscal deficits (Figure 2).

However, after the sharp reduction in debt from 2006 (second phase) and the marked improvement in the fiscal balance during the same year (Figure 2), the fiscal balances for the majority of countries and the Union have deteriorated (Figures 1 and 2). This is largely because countries took advantage of debt relief programs since 2006 to boost their economic activity through significant public expenditures, particularly in the infrastructure sector (Figure 5). In turn, based on Agbékponou and Kebalo (2019), the increase in public expenditures, which contributed to the deterioration of fiscal balances, has contributed to a further increase in the level of debt (Figure 4).

Given the existence of this break and the two different phases in the evolution of the budget balance in the Union, we factor this as we pursue our research objective and consider the two phases (1990 to 2005 and 2006 to 2018) in our analysis. We believe that the change in the behavior of the fiscal balance could endogenously influence the value of the fiscal deficit threshold that maximizes economic growth in the Union.

Figure 1. Overall fiscal balance including grants (\% of the Gross Domestic Product (GDP)) of West African Economic and Monetary Union (WAEMU) member countries
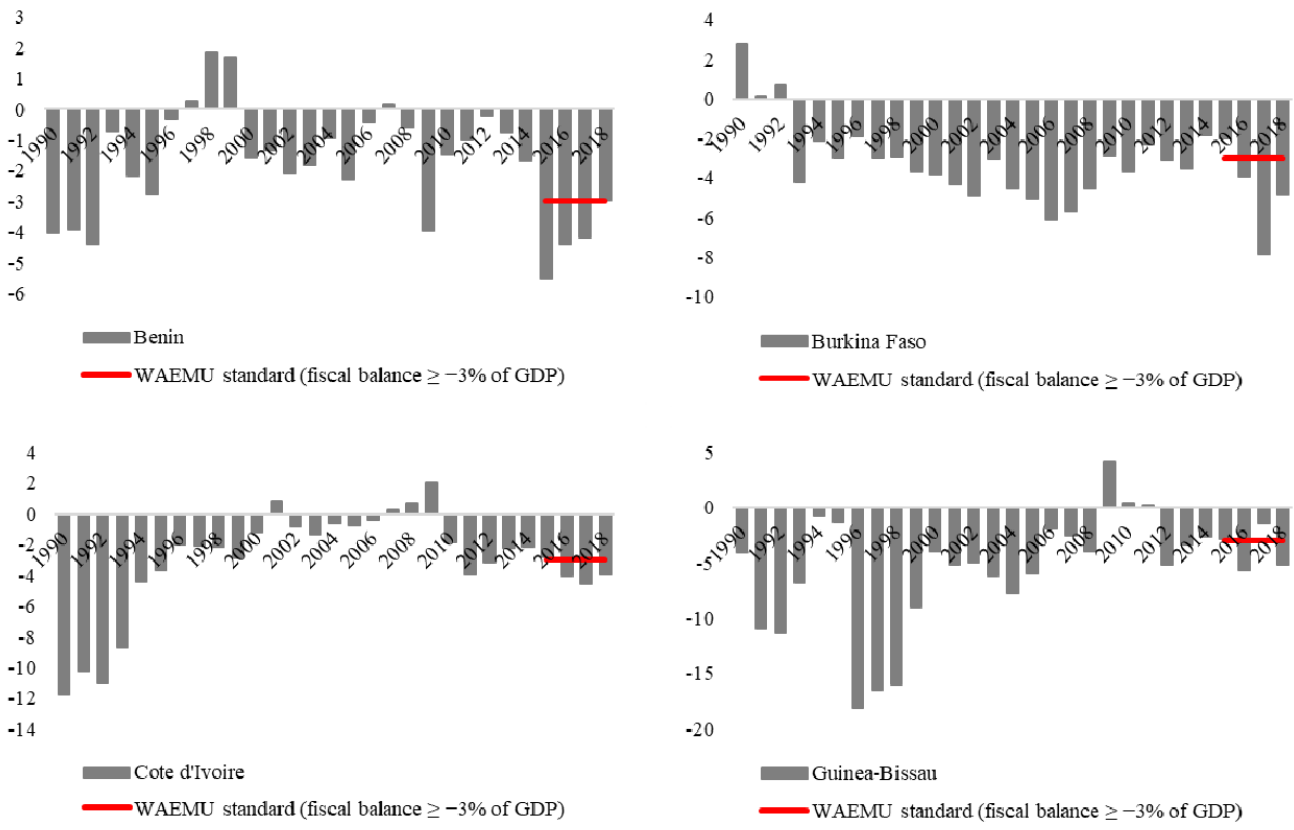
Figure 1. Continued
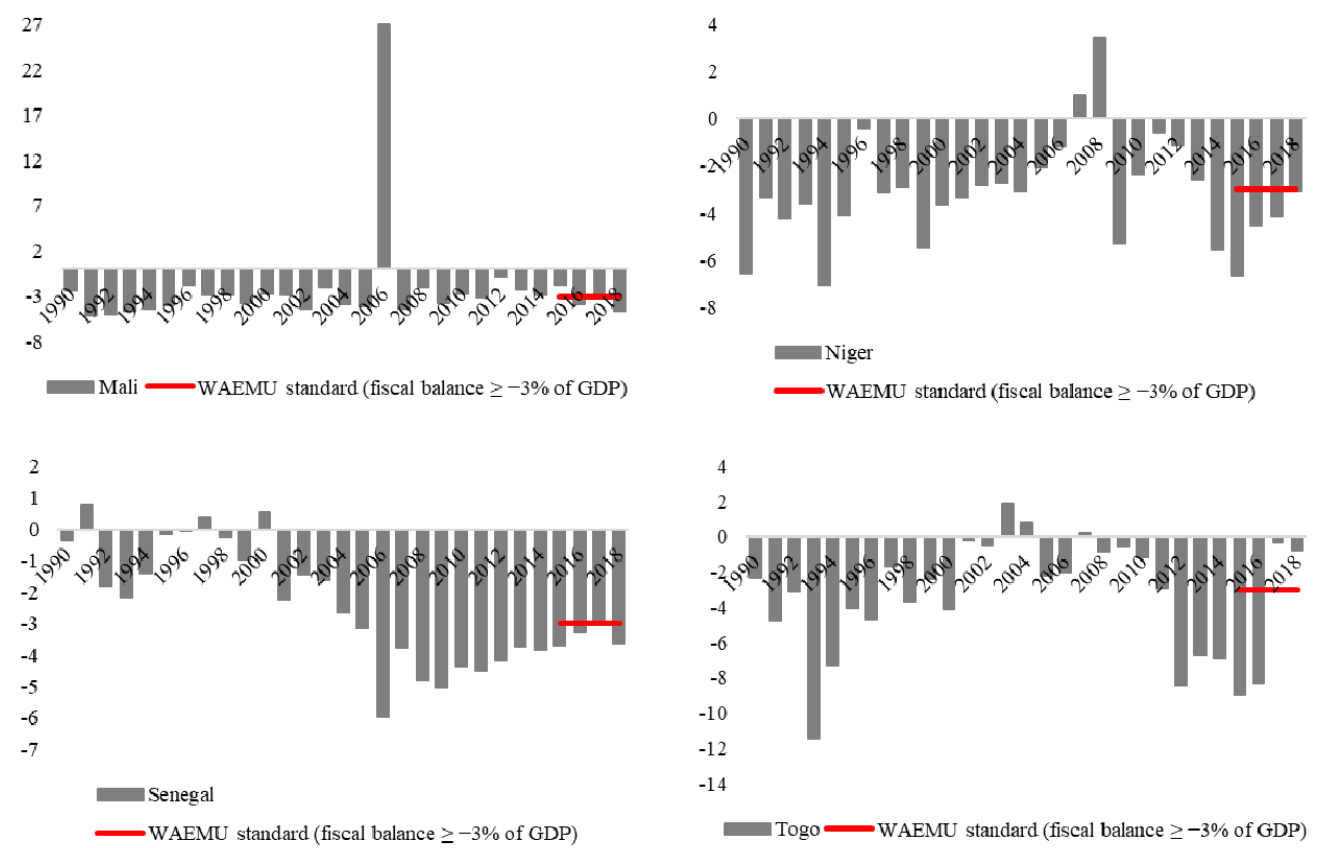

Note. The fiscal standard limiting fiscal deficit to 3\% of the GDP came into force in 2015.

Source: Authors, based on African Development Bank (AfDB) data.

Figure 2. Overall fiscal balance (\% of Gross Domestic Product (GDP)) for the West African Economic and Monetary Union (WAEMU) zone

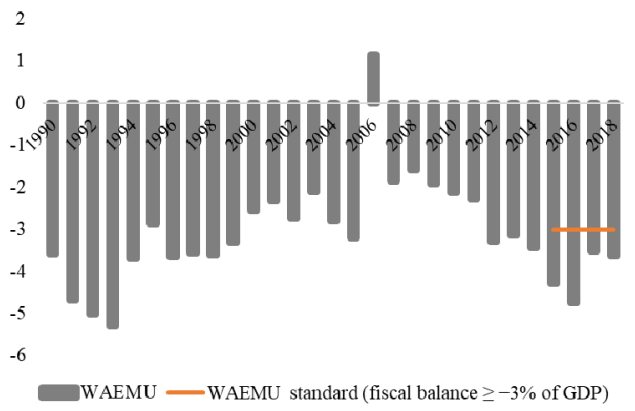

Figure 3. Tax revenues (\% of Gross Domestic Product (GDP)) in the West African Economic and Monetary Union (WAEMU) zone

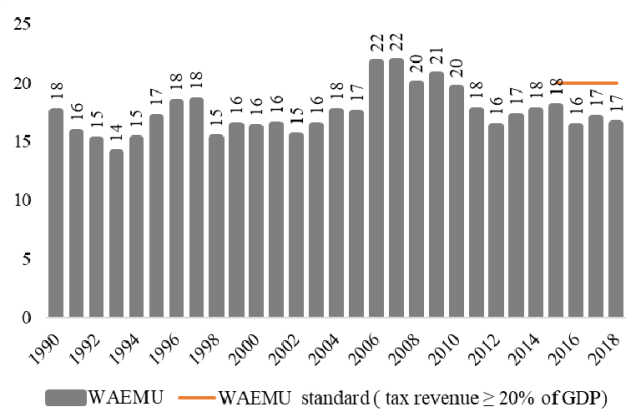


Figure 4. Outstanding public debt (\% of Gross Domestic Product (GDP)) in the West African Economic and Monetary Union (WAEMU) zone

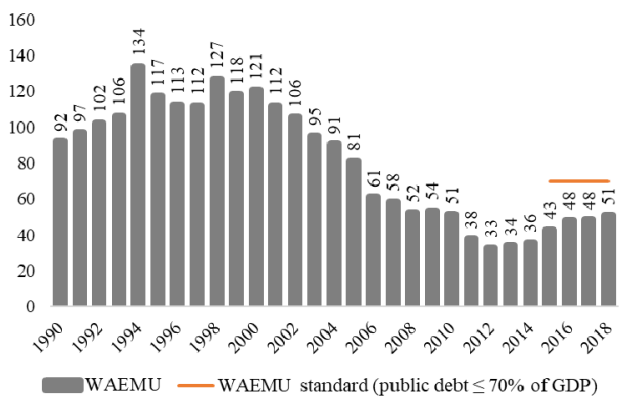

Figure 5. Public expenditures (\% of Gross Domestic Product (GDP)) in the West African Economic and Monetary Union (WAEMU) zone

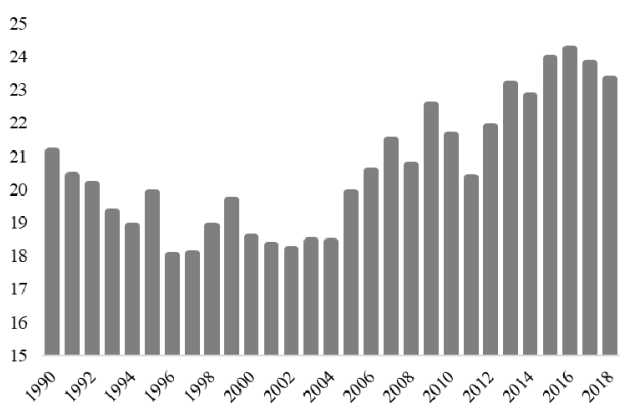

Note. In January 2015, Additional Act No. 1/2015/CCEG/UEMOA established a new Convergence Pact in WAEMU. The convergence horizon is set at 2019. This Pact contains three first-order and two second-order criteria. The three new first-order criteria are, among others, (i) the ratio of the overall fiscal balance, including grants, to nominal GDP $\geq-3 \%$, (ii) the average annual inflation rate $\leq 3 \%$, and (iii) the ratio of domestic and external debt stock to nominal GDP $\leq 70 \%$. The two new second-order criteria relate to the ratios of the wage bill to tax revenue $\leq 35 \%$ and tax revenue to nominal GDP $\geq 20 \%$.

Source: Authors, based on African Development Bank (AfDB) data.

\section{Methodology}

\section{A. Estimate of the endogenous fiscal deficit threshold}

To determine the endogenous fiscal deficit threshold, we adopted Hansen's (1999) panel model with the threshold effect based on three reasons.

First, economic literature demonstrates that Hansen's (1999) approach makes it possible to factor the nonlinearity of a relation and/or the temporal heterogeneity and instability of slope coefficients. Therefore, it is possible to model situations where the economic relationship between a dependent variable and an independent variable changes from one regime to another, depending on an estimated threshold (Fouquau, 2008). Second, the thresholds estimated using this approach better reflects economic realities, while accounting for temporal and individual dimensions (Alagidede et al., 2018; Hansen, 1999; Ndoricimpa, 2017). Third, the approach can be used in various fields to estimate thresholds. Hansen initially used it to describe the nonlinear link between firms' investment behaviors and the financial constraints that they experience. Hurlin (2005) uses the approach to highlight the networks effects in the analysis of infrastructures productivity through threshold effects, while Savvides and Stengosb (2000) adopt it to represent the Kuznets curve linking inequalities to economic development. Moreover, the approach allows an analysis of disaggregated data, which better brings to light economic dynamics and individual heterogeneities (Canry et al., 2007). 
In general, Hansen's (1999) one-threshold nonlinear model can be written as,

$$
G_{i, t}=\mu_{i}+\beta_{1} X_{i, t} I\left(q_{i, t} \leq \gamma\right)+\beta_{2} X_{i, t} I\left(q_{i, t}>\gamma\right)+\epsilon_{i, t}
$$

with $q_{i, t}$ corresponding to the transition variable, $\gamma$ to the threshold, $G_{i, t}$ to the dependent variabl $\mathrm{e}, X_{i, t}$ to the independent variable, $\Pi$ (.) to the indicator function, $\mu_{i}$ to the fixed effects, $\beta_{1}$ and $\beta_{2}$ and to the model's parameters, respectively.

The endogenous variable is the real GDP per capita growth rate of WAEMU countries $(G)$. The overall fiscal balance, including grants $(F B)$ is both the interest variable and transition variable. Regarding economic literature and given data availability, we retain a certain number of control variables. Economic literature shows that some factors may influence a geographical entity's economic growth, from which, we picked four.

First, we retained the gross capital formation $(G C F)$, which has a positive effect on economic growth (Keynesian theory). Second, we retained trade openness (Open), which is largely perceived as an economic policy that allows for the improvement of a countries' growth rate (Zahonogo, 2017). Third, we retained the population growth rate $(P O P)$ because demography could have a positive or negative effect on economic growth (Amadou \& Kebalo, 2019; Zahonogo, 2017). Regarding WAEMU, Agbékponou and Kebalo (2019) find that population growth enables sustained economic growth through the demand channel. Fourth, we built in a dummy variable $D F B$ that assumes the value of 1 when countries of the Union present a fiscal balance, including grants $\geq$ the estimated threshold and 0 , otherwise. This variable allows for measuring the effect on the economic growth of a country presenting an overall fiscal balance, including grants (\% of the GDP) $\geq$ the estimated threshold. Essentially, this variable allows for measuring the effect on economic growth for a country that does not present a fiscal deficit exceeding the estimated GDP threshold.

Table 1 presents the sources and measures of variables considered in the first analysis (1990-2018).

Table 1. Definition and Variables Sources

\begin{tabular}{lll}
\hline Variables & \multicolumn{1}{c}{ Definition } & \multicolumn{1}{c}{ Sources } \\
\hline$G$ & Real GDP per capita growth rate (\%) & World Bank (WDI) \\
$F B$ & Overall fiscal balance, including grants (\% of the GDP) & African Economic Outlook (AfDB Group) \\
$G C F$ & Gross Capital Formation (\% of the GDP) & African Economic Outlook (AfDB Group) \\
Open & Trade (\% of the GDP) & World Bank (WDI) \\
$P O P$ & Total population growth rate (\%) & World Bank (WDI) \\
$D F B$ & 1 when fiscal balance, including grants (\% of the GDP) $\geq$ & Authors \\
& to the estimated threshold and 0, otherwise & \\
\hline
\end{tabular}

Note. GDP: gross domestic product; AfDB: African Development Bank; WDI: world development indicators. 
Before moving on to specification and estimation stages, we carried out Im et al. (2003) and Levin et al. (2002) panel data unit root tests on the selected variables, except for the $D F B$. Tests results (Table 2) indicate that all variables are stationary.

Table 2. Unit Root Tests

\begin{tabular}{lcc}
\hline & IPS & LLC \\
\hline$G$ & -7.8118 & $-3,7676$ \\
& $(0.0000)$ & $(0.0001)$ \\
& -4.6050 & -3.0389 \\
GCF & $(0.0000)$ & $(0.0012)$ \\
& $-2,0360$ & $-1,6667$ \\
Open & $(0.0209)$ & $(0.0478)$ \\
& $-1,9873$ & -4.6740 \\
POP & $(0.0308)$ & $(0.0000)$ \\
& -2.3619 & $-6,7617$ \\
\hline
\end{tabular}

Note. $G$ : Real GDP per capita growth rate (\%);FB: Overall fiscal balance, including grants (\% of the GDP); GCF: Gross Capital Formation (\% of the GDP); Open: Trade (\% of the GDP); POP. Total population growth rate (\%). (.) probabilities associated with tests statistics; LLC and IPS respectively refer to the tests of Im et al. (2003) and Levin et al. (2002). The null hypothesis for both the tests is the presence of unitary root. Source: Authors.

\section{B. Compliance with the key fiscal convergence criterion and business cycles synchronization}

The European experience provided an opportunity to test the criteria of an Optimal Currency Area and introduce more political criteria such as the homogeneity of preferences (Cooper, 1974; Kindleberger, 1986). Here, one of the objectives of the creation of the Economic and Monetary Union was to pursue integration through the convergence of its economies. For that, the homogeneity of preferences of the European countries, candidates for monetary union, were attested and formalized by the signing of the Maastricht Treaty (1992), which makes the adoption of the European currency subject to compliance with several convergence criteria by all candidate countries.

The convergence of countries describes a process of a macroeconomic nature according to which countries with similar characteristics should see their rate of economic growth converge toward a similar regular rate (Diop, 2002). As such, nominal convergence is a process of bringing together economies, concerning certain key variables indicative of macroeconomic stability (e.g., inflation rate, budget deficit, exchange rate, public debt ratio, etc.). Within WAEMU, the convergence of economies was materialized through the Convergence, Stability, Growth, and Solidarity Pact instituted by additional Act of 1999 .

Essentially, through the nominal convergence of economies, their real convergence would 
gradually come closer. Through this, Bamba (2000) estimated that the convergence criteria of the Maastricht Treaty (1992), aimed at price and exchange rate stability, would promote trade between member countries, which would promote them to come closer in their structures and levels of development. He argues that countries that reach common nominal targets would guarantee the convergence of their GDP per capita, levels of development, and guarantees of viable economic and monetary unions. Thus, we believe that through compliance with the WAEMU Convergence Pact's criteria, especially the one related to fiscal deficit, the countries' economic structures would come closer and therefore, their business cycles would synchronize.

We used panel data estimation techniques to illustrate that countries that comply with the key fiscal convergence criterion to a certain threshold tend to improve their business cycles synchronization.

To measure the degree of business cycles synchronization between countries $i$ and $j$ at time t, most studies (Baxter \& Kouparitsas, 2005; Caldéron et al., 2007; Inklaar et al., 2008; Tapsoba, 2009) follow Frankel and Rose (1998) and compute the correlation between the cyclical components of output for countries $i$ and $j$ :

$$
\operatorname{Cor}\left(y_{i}^{c}, y_{j}^{c}\right)=\frac{\operatorname{cov}\left(y_{i}^{c}, y_{j}^{c}\right)}{\sqrt{\operatorname{var}\left(y_{i}^{c}\right) \times \operatorname{var}\left(y_{j}^{c}\right)}}
$$

where $y^{c}$ is the cyclical component of output $(y)$ and, $y$ is the (log of the) real GDP (constant 2010 US). The cyclical component of output $\left(y^{c}\right)$ is obtained using different de-trending techniques ${ }^{6}$. Once we obtain the cyclical component of the output for all countries, we compute bilateral correlations of real activity. The length of the business cycle is close to the duration from 6 to 32 quarters (i.e., 1.5 to 8 years) as originally recommended by Baxter and King (1999). Higher correlations imply a higher degree of synchronization.

However, this measure is not easily observable at high frequency (annually or quarterly) and does not consider temporal variability (Zouri, 2020). Additionally, it is sensitive to the various filtering methods used in extracting business cycles, which are criticized for many reasons (Canova, 1998, 1999)7). That is why recent literature (Cesa-Bianchi et al., 2019; Giannone \& Reichlin, 2010; IMF, 2013; Kalemli-Ozcan et al., 2013; Kebalo \& Zouri, 2021; Zouri, 2020) uses a new approach that considers the limits mentioned above. According to this literature, the synchronization between two economies $i$ and $j$ is measured based on the absolute differential in the real GDP (per capita) growth rate between these economies:

6) See Baxter and King's (1999) filter and Hodrick and Prescott's (1997) filter.

7) One of the problems with the filtering method is the uncertainty about the appropriate value of the smoothing parameter for the annual data: Hodrick and Prescott (1997) initially propose 100, while Ravn and Uhlig (2002) recommend 6.25 . 


$$
S_{i j, t}=-\left|G_{i, t}-G_{j, t}\right|
$$

where $G_{i, t}$ and $G_{j, t}$ represent the growth rate of real GDP per capita at $t$ for countries $i$ and $j$, respectively. The definition ${ }^{8)}$ is such that $S_{i j, t}$ increases with the degree of synchronization with negative values close to zero, among countries presenting synchronized cycles.

From the above equation, we rely on the second approach even if for the sake of robustness check, we later come back to the first.

To analyze the relationship between compliance with the fiscal convergence threshold and the business cycles synchronization, we estimate:

$$
S_{i j, t}=\alpha_{i j}+\gamma_{t}+\beta_{1} \times D F B_{i j, t}+\beta_{2} \times T I_{i j, t}+\beta_{3} \times F C_{i j, t-1}+\eta_{i j, t}
$$

where $\gamma_{t}$ represents the yearly effects, which consider global shocks that affect all countries homogeneously. Compared to the literature (Baxter \& Kouparitsas, 2005; Frankel \& Rose, 1998; Tapsoba, 2009), we introduce $\alpha_{i j}$ to factor the country pair specific effect.

$D F B_{i j, t}$ is our interest variable that takes the value of 1 if the pair of countries $i, j$ at $t$ comply with the fiscal balance over GDP ratio $\geq$ the estimated threshold and 0 , otherwise. For robustness, we verify whether the fact of presenting an overall fiscal balance (including grants) over GDP ratio $\geq-3 \%$ as defined in WAEMU's current Growth and Convergence Pact, also contributes to increasing the business cycles synchronization. Our $T I$ and $F C$ control variables represent bilateral trade (trade intensity) and fiscal convergence, respectively.

$T I$ is the bilateral trade ratio between the pair of countries $i, j$ on the sum of their total trade $^{9)}$ (Baxter \& Kouparitsas, 2005; Couchoro et al., 2022; Dout \& Kebalo, 2021; Frankel \& Rose, 1998; Tapsoba, 2009). Given the possible endogeneity of bilateral trade, we instrumentalize bilateral trade with bilateral trade costs following Egger et al. (2019) and Zouri (2020).

$F C$ is based on the absolute difference for public expenditures ${ }^{10)}$ between the pair of countries $i, j$ in proportion of their GDPs (Dout \& Kebalo, 2021; Gammadigbe et al., 2018; Kebalo \& Zouri, 2021; Mpatswe et al., 2011). Following Kalemli-Ozcan (2013), we took a first-order (1-year) lag for fiscal convergence to take into account possible endogeneity problems.

8) This measure presents advantages. It is easily observable at high frequency (annual, quarterly) and factors temporal variability, contrary to the correlation coefficient often used (Caldéron et al., 2007; Inklaar et al., 2008; Frankel \& Rose, 1998; Tapsoba, 2009). Moreover, it is not sensitive to the various filtration methods used in economic cycles extraction (Canova, 1998, 1999).

9) This measure is preferred to the bilateral trade ratio between two economies on the sum of their GDPs. The latter was the object of multiple criticism, notably that regarding the size of the country (Samimi et al., 2011; Riezman et al., 2013).

10) This measure is preferred over the one defined on the basis of the absolute difference of the fiscal balance of public administrations between the pair of countries, , in relation to their GDP. The latter is the object of multiple criticisms as described in Reinhart et al. (2004). 
To consolidate our results, we made use of another estimation technique to analyze the link between the fact of presenting a fiscal balance $\geq-3 \%$ of the GDP and the synchronization of business cycles. For that, we relied on the generalized method of moments (GMM method) in the dynamic panel that allowed us to find solutions to issues of simultaneity bias, reverse causality, and omitted variables. Besides, the GMM method provides the results of Hansen's over-identification test and Arellano and Bond's (1991) error autocorrelation test to examine the validity of the lagged or delayed variables as instruments and the null hypothesis of the lack of second-order autocorrelation of errors in the equation indifference. Based on Blundell and Bond (1998), the system GMM estimator was privileged ${ }^{11)}$.

Annual data used are obtained from the World Bank's world development indicators for the GDP per capita (constant US 2010). Bilateral exports and imports data (current US), total exports (respectively total imports) to the rest of the world (respectively from the rest of the world) are obtained from the IMF's Direction of Trade Statistics. Data for fiscal balances and public expenditures or spending are taken from the African Development Bank Group's database. Due to the unavailability of some information, there is an imbalance in the panel data. For this reason, heteroscedasticity is corrected using the cluster method ${ }^{12}$.

\section{Results}

\section{A. Identification of the endogenous fiscal deficit threshold}

For a better specification of the model, we carried out the linearity test (Table 3). The results indicate the existence of a nonlinear structure characterized by two regimes and an endogenous fiscal deficit threshold estimated at $-11.42 \%$ of the GDP and significant at $5 \%$.

Table 3. Linearity Test

\begin{tabular}{ccccccc}
\hline \multicolumn{2}{c}{ Threshold } & & \multirow{2}{*}{ SSR } & MSE & F-Stat & Prob \\
\cline { 1 - 2 } Number & Value & & & & 0.037 \\
\hline 1 & -11.42 & & 4561.37 & 22.470 & 10.35 & 0.35 \\
\hline
\end{tabular}

Note. bootstrap $=300$; SSR: sum of squared residuals; MSE: mean squared errors; F-stat: Fisher's statistical test; Prob: probabilities related to Fisher's statistical test.

Source: Authors' estimates.

11) The instrumentation method differs depending on the nature of explanatory variables: (a) for purely exogenous variables, current variables are used as instruments; (b) for slightly exogenous variables, values delayed by at least one period are used as instruments; (c) for endogenous variables, values delayed by two periods and more can be used as valid instruments.

12) The cluster method specifies that standard errors allow for intra-group correlation, thus giving more flexibility to the usual requirement that observations be independent; this means that observations are independent from amongst groups (clusters) but not necessarily within a specific group. 
The estimated model takes the following form:

$$
G_{i, t}=\mu_{i}+\beta_{1} F B_{i, t} I\left(F B_{i, t} \leq \gamma\right)+\beta_{2} F B_{i, t} I\left(F B_{i, t}>\gamma\right)+\Gamma^{\prime} X_{i, t}+\epsilon_{i, t}
$$

$X_{i, t}$ is the vector containing the control variables $G C F$, Open, POP, and DFB.

Table 4 presents the results obtained from estimates. Regarding control variables, our results show first that gross capital formation and trade openness have a positive effect on economic growth, complementing the results achieved by Amadou and Kebalo (2019) and Zahonogo (2017). Subsequently, the results show that population growth within WAEMU does not affect economic growth. Finally, they highlight that, independently of WAEMU countries, not exceeding a fiscal deficit of $3 \%$ of the GDP contributes to improving economic growth. This is why WAEMU countries should make efforts to comply with the key convergence criterion limiting the fiscal deficit to $3 \%$ of the GDP.

Table 4. Results of the Nonlinear Effect of Fiscal Balance on Economic Growth in West African Economic and Monetary Union (WAEMU)

\begin{tabular}{|c|c|c|c|c|}
\hline & Model 1 & Model 2 & Model 3 & Model 4 \\
\hline & Coef. & Coef. & Coef. & Coef. \\
\hline$\gamma$ & $-11.42 * *$ & $-11.42 * *$ & $-11.42 * *$ & $-11.42 * *$ \\
\hline Intercept & $\begin{array}{c}1.03 \\
(0.98)\end{array}$ & $\begin{array}{l}-0.82 \\
(-0.42)\end{array}$ & $\begin{array}{c}0.62 \\
(0.17)\end{array}$ & $\begin{array}{c}-0.33 \\
(-0.09)\end{array}$ \\
\hline$F B \geq \gamma$ & $\begin{array}{c}0.44 * * * \\
(3.03)\end{array}$ & $\begin{array}{c}0.43 * * * \\
(2.92)\end{array}$ & $\begin{array}{c}0.43 * * * \\
(2.95)\end{array}$ & $\begin{array}{l}0.36^{* * *} \\
(2.38)\end{array}$ \\
\hline$F B<\gamma$ & $\begin{array}{c}-0.05 \\
(-0.48)\end{array}$ & $\begin{array}{c}-0.06 \\
(-0.62)\end{array}$ & $\begin{array}{c}-0.06 \\
(-0.64)\end{array}$ & $\begin{array}{c}-0.19 \\
(-1.53)\end{array}$ \\
\hline$G C F$ & $\begin{array}{c}0.19 * * * \\
(3.53)\end{array}$ & $\begin{array}{c}0.17 * * * \\
(2.80)\end{array}$ & $\begin{array}{c}0.17 * * * \\
(2.83)\end{array}$ & $\begin{array}{c}0.17 * * * \\
(2.91)\end{array}$ \\
\hline Open & & $\begin{array}{l}0.04 * \\
(1.85)\end{array}$ & $\begin{array}{l}0.04 * \\
(1.87)\end{array}$ & $\begin{array}{l}0.03 * \\
(1.83)\end{array}$ \\
\hline$P O P$ & & & $\begin{array}{l}-0.50 \\
(-0.46)\end{array}$ & $\begin{array}{c}-0.40 \\
(-0.37)\end{array}$ \\
\hline$D F B$ & & & & $\begin{array}{l}1.36^{*} \\
(1.69)\end{array}$ \\
\hline CI of $\gamma$ & {$[-14.15 ;-11.32]$} & {$[-14.15 ;-11.32]$} & {$[-14.15 ;-11.32]$} & {$[-14.15 ;-11.32]$} \\
\hline F-stat & $3.44 * * *$ & $3.58 * * *$ & $3.45^{* * *}$ & $4.98 * * *$ \\
\hline Prob $>\mathrm{F}$ & 0.002 & 0.001 & 0.002 & 0.000 \\
\hline Obs & 232 & 232 & 232 & 232 \\
\hline
\end{tabular}

Note. FB: Overall fiscal balance, including grants (\% of the GDP); GCF: Gross Capital Formation (\% of the GDP); Open: Trade ( $\%$ of the GDP); POP: Total population growth rate $(\%)$. DFB takes value 1 when the pair country of WAEMU presents fiscal balance (including grants) $\geq-11.423 \%$ of GDP and 0 , otherwise. CI: confidence interval. $* * *, * *$, and $*$ for significance at $1 \%, 5 \%$, and $10 \%$, respectively. (.) t-statistics.

Source: Authors' estimates. 
Regarding the nonlinear relation, the results show that the fiscal balance has a positive effect on economic growth when the recorded fiscal deficit does not exceed $11.42 \%$. However, when it does, the fiscal balance has no effect on economic growth. Based on these results, we can conclude that the convergence criterion in force in the Union is pro-growth because its value is not higher than the estimated threshold. These results corroborate Amadou and Kebalo (2019).

\section{B. Key fiscal convergence criterion and business cycles synchronization}

We establish an economic foundation regarding compliance with the various thresholds selected by analyzing the implication of compliance in business cycles synchronizations.

Table 5 shows how, at several levels of robustness, a country pair of WAEMU presenting, during the same period, fiscal balances higher than $-11.42 \%$ of the GDP tends to view their business cycles as being more synchronized. Conversely, when countries present a fiscal deficit exceeding $11.42 \%$, business cycles synchronization does not increase. Thus, for countries within the zone, not exceeding a fiscal deficit of $11.42 \%$ of the GDP, improves economic growth and increases business cycles synchronization.

Since the fiscal convergence criterion in force within WAEMU (overall fiscal balance, including grants, $\geq-3 \%$ of the GDP) is higher than $-11.42 \%$ of the GDP, countries within the Union presenting fiscal balances higher than $-3 \%$ during the same period tend to see their business cycles as being more synchronized. Table 6 confirms our conclusion. Indeed, the results show that the improvement of fiscal convergence within WAEMU is favorable to business cycles synchronization.

Table 5. Compliance or not with the Estimated Threshold and Business Cycles Synchronization in West African Economic and Monetary Union (WAEMU)

\begin{tabular}{|c|c|c|c|c|}
\hline \multicolumn{5}{|c|}{ Business cycles synchronization $S_{i j, t}$} \\
\hline & \multicolumn{2}{|c|}{$\begin{array}{l}\text { Compliance with estimated threshold } \\
\qquad F B \geq-11.42 \% \text { of the GDP }\end{array}$} & \multicolumn{2}{|c|}{$\begin{array}{l}\text { Non-compliance with estimated threshold } \\
\qquad F B<-11.42 \% \text { of the GDP }\end{array}$} \\
\hline & Within estimator & System GMM estimator & Within estimator & System GMM estimator \\
\hline$D F B_{i j, t}$ & $\begin{array}{c}5.42 * * * \\
(0.85)\end{array}$ & $\begin{array}{c}13.7 * * * \\
(5.07)\end{array}$ & $\begin{array}{c}\mathbf{0 . 8 5} \\
(0.89)\end{array}$ & $\begin{array}{l}\mathbf{1 0 1 . 1 7} \\
(89.48)\end{array}$ \\
\hline$T I_{i j, t}$ & $\begin{array}{l}25.26^{* * * *} \\
(6.55)\end{array}$ & $\begin{array}{c}15.11 \\
(39.74)\end{array}$ & $\begin{array}{l}28.99 * * * \\
(7.46)\end{array}$ & $\begin{array}{l}-16.44 \\
(32.08)\end{array}$ \\
\hline$F C_{i j, t-1}$ & $\begin{array}{l}11.83^{*} \\
(6.83)\end{array}$ & $\begin{array}{l}-2.11 \\
(25.95)\end{array}$ & $\begin{array}{c}19.49 * * \\
(8.49)\end{array}$ & $\begin{array}{l}-25.62 * \\
(14.58)\end{array}$ \\
\hline$S_{i j, t-1}$ & - & $\begin{array}{l}0.01 * \\
(0.05)\end{array}$ & - & $\begin{array}{c}0.06 \\
(0.05)\end{array}$ \\
\hline Observations & 644 & 642 & 644 & 642 \\
\hline Country pairs & 28 & 28 & 28 & 27 \\
\hline $\mathrm{R}^{2}$ (within) & 0.3157 & - & 0.2546 & - \\
\hline Specific fixed effect & Yes & - & Yes & - \\
\hline Temporal fixed effect & Yes & Yes & Yes & Yes \\
\hline
\end{tabular}


44 Journal of Economic Integration Vol. 37, No. 1

Table 5. Continued

\begin{tabular}{|c|c|c|c|c|}
\hline \multicolumn{5}{|c|}{ Business cycles synchronization $S_{i j, t}$} \\
\hline & \multicolumn{2}{|c|}{$\begin{array}{l}\text { Compliance with estimated threshold } \\
\qquad F B \geq-11.42 \% \text { of the GDP }\end{array}$} & \multicolumn{2}{|c|}{$\begin{array}{l}\text { Non-compliance with estimated threshold } \\
\qquad F B<-11.42 \% \text { of the GDP }\end{array}$} \\
\hline & Within estimator & System GMM estimator & Within estimator & System GMM estimator \\
\hline \multicolumn{5}{|c|}{ First stage estimate using the instrumental variables method } \\
\hline Explanatory variables & $T I_{i j, t}$ & & $T I_{i j, t}$ & \\
\hline$\lambda_{i j, t}$ & $\begin{array}{c}18.22 * * * \\
(0.67)\end{array}$ & & $\begin{array}{c}18.21^{* * *} \\
(0.67)\end{array}$ & \\
\hline$D F B_{i j, t}$ & $\begin{array}{l}-0.0004 \\
(0.002)\end{array}$ & & $\begin{array}{c}0.005^{* * * *} \\
(0.002)\end{array}$ & \\
\hline$F C_{i j, t-1}$ & $\begin{array}{l}-0.02 \\
(0.01)\end{array}$ & & $\begin{array}{l}-0.02 \\
(0.01)\end{array}$ & \\
\hline Specific fixed effect & Yes & & Yes & \\
\hline Temporal fixed effect & Yes & & Yes & \\
\hline \multicolumn{5}{|c|}{ GMM test } \\
\hline $\begin{array}{l}\text { Arellano-Bond test: } \\
\operatorname{AR}(2)\end{array}$ & & $\begin{array}{c}0.09 \\
{[0.93]}\end{array}$ & & $\begin{array}{c}-0.84 \\
{[0.401]}\end{array}$ \\
\hline $\begin{array}{l}\text { Hansen test: H0 } \\
\text { (exogenous instruments) }\end{array}$ & & $\begin{array}{c}41 \\
{[0.12]}\end{array}$ & & $\begin{array}{c}18.02 \\
{[0.11]}\end{array}$ \\
\hline $\begin{array}{l}\text { Number of } \\
\text { instruments }\end{array}$ & & 63 & & 46 \\
\hline F-statistic & & $58.34 * * *$ & & $33.89 * * *$ \\
\hline
\end{tabular}

Note. $\mathrm{S}_{\mathrm{ij}, \mathrm{t}}$ : business cycles synchronization between countries $\mathrm{i}$ and $\mathrm{j}$ at $\mathrm{t} ; \mathrm{S}_{\mathrm{ijt}-1}$ : a first-order (1-year) lag for business cycles synchronization; $\mathrm{TI}_{\mathrm{ij}, \mathrm{t}}$ : bilateral trade between countries $\mathrm{i}$ and $\mathrm{j}$ at $\mathrm{t} ; \mathrm{FC}_{\mathrm{ij}, \mathrm{t}}$ : fiscal convergence between countries $\mathrm{i}$ and $\mathrm{j}$ at $\mathrm{t} ; \mathrm{FC}_{\mathrm{ij}, \mathrm{t}-1}$ : a first-order (1-year) lag for fiscal convergence. DFB, takes value 1 when the pair-country of WAEMU presents fiscal balance (including grants) $\geq-11.42 \%$ of GDP and 0 , otherwise. $\lambda_{i j, t}$ represents the costs of bilateral trade. [.] P-value; (.) robust standard deviations; *** $p<0.01 ; * * p<0.05$; and * $p<0.1$.

Source: Authors' estimates.

Table 6. Compliance with the Key Fiscal Convergence Criterion (FB $\geq-3 \%$ of the Gross Domestic Product (GDP)) and Business Cycles Synchronization

\begin{tabular}{|c|c|c|c|c|c|c|}
\hline \multicolumn{7}{|c|}{ Business cycles synchronization $\left(S_{i j, t}\right)$} \\
\hline \multirow{2}{*}{ Explanatory variables } & \multicolumn{3}{|c|}{ Within estimator } & \multicolumn{3}{|c|}{ System GMM estimator } \\
\hline & (1) & (2) & (3) & (4) & (5) & (6) \\
\hline$D F B_{i j, t}$ & $\begin{array}{l}1.1 \% * * \\
(0.25)\end{array}$ & $\begin{array}{c}\mathbf{0 . 8 5} * * * \\
(0.29)\end{array}$ & $\begin{array}{l}\mathbf{0 . 4 2 \% *} \\
(0.18)\end{array}$ & $\begin{array}{c}12,1 * * * \\
(4.20)\end{array}$ & $\begin{array}{l}\mathbf{8 , 2} \div * * \\
(2.43)\end{array}$ & $\begin{array}{l}7,9 \div \div * \\
(1.89)\end{array}$ \\
\hline$T I_{i j t}$ & & $\begin{array}{c}19.8 * * * \\
(5.06)\end{array}$ & $\begin{array}{c}29.7 * * * \\
(7.33)\end{array}$ & & $\begin{array}{c}2.73 \\
(38.22)\end{array}$ & $\begin{array}{c}-4.32 \\
(23.11)\end{array}$ \\
\hline$F C_{i j, t-1}$ & & & $\begin{array}{c}18.8 * * * \\
(8.27)\end{array}$ & & & $\begin{array}{l}31.1^{* *} \\
(12.08)\end{array}$ \\
\hline$S_{i j, t-1}$ & - & - & - & $\begin{array}{l}-0.60 * \\
(0.32)\end{array}$ & $\begin{array}{c}0.10^{* *} \\
(0.05)\end{array}$ & $\begin{array}{c}0.04 \\
(0.06)\end{array}$ \\
\hline
\end{tabular}


Table 6. Continued

\begin{tabular}{|c|c|c|c|c|c|c|}
\hline \multicolumn{7}{|c|}{ Business cycles synchronization $\left(S_{i j, t}\right)$} \\
\hline \multirow{2}{*}{ Explanatory variables } & \multicolumn{3}{|c|}{ Within estimator } & \multicolumn{3}{|c|}{ System GMM estimator } \\
\hline & $(1)$ & $(2)$ & (3) & (4) & $(5)$ & (6) \\
\hline Observations & 812 & 670 & 644 & 784 & 648 & 642 \\
\hline Countries pairs & 28 & 28 & 28 & 28 & 28 & 27 \\
\hline $\mathrm{R}^{2}$ (within) & 0.2449 & 0.2136 & 0.2567 & - & - & - \\
\hline Specific fixed effect & Yes & Yes & Yes & - & - & - \\
\hline Temporal fixed effect & Yes & Yes & Yes & Yes & Yes & Yes \\
\hline
\end{tabular}

First stage of estimate using the instrumental variables method

\begin{tabular}{lcc}
\hline \multirow{2}{*}{ Explanatory variables } & $T_{i j t}$ \\
\cline { 2 - 3 } & $(2)$ & $(3)$ \\
\hline$\lambda_{i j t}$ & $18.48^{* * *}$ & $18.25^{* * *}$ \\
& $(0.76)$ & $(0.68)$ \\
$D F B_{i j, t}$ & 0.001 & 0.001 \\
& $(0.001)$ & $(0.001)$ \\
$F C_{i j, t-1}$ & - & -0.02 \\
& & $(0.01)$ \\
Specific fixed effect & Yes & Yes \\
Temporal fixed effect & Yes & Yes \\
\hline
\end{tabular}

\begin{tabular}{lccc}
\hline \multicolumn{1}{c}{ GMM } & \multicolumn{3}{c}{ GMM tests } \\
\hline Arellano-Bond test: & -1.42 & $(5)$ & $(6)$ \\
AR(2) & {$[0.15]$} & 1.09 & -0.94 \\
Hansen test: H0 & 2 & {$[0.27]$} & {$[0.27]$} \\
(exogenous instruments) & {$[0.37]$} & 6.63 & 42.42 \\
Number of & 34 & {$[0.83]$} & {$[0.13]$} \\
instruments & & 44 & 63 \\
F-statistic & $732.77^{* * *}$ & $399.6^{* * *}$ & $75.36^{* * *}$ \\
\hline
\end{tabular}

Note. $\mathrm{S}_{\mathrm{ij}, \mathrm{t}}$ : business cycles synchronization between countries $\mathrm{i}$ and $\mathrm{j}$ at $\mathrm{t} ; \mathrm{S}_{\mathrm{ijt}-1}$ : a first-order (1-year) lag for business cycles synchronization; $\mathrm{TI}_{\mathrm{ij}, \mathrm{t}}$ : bilateral trade between countries $\mathrm{i}$ and $\mathrm{j}$ at $\mathrm{t} ; \mathrm{FC}_{\mathrm{ij}, \mathrm{t}}$ : fiscal convergence between countries $\mathrm{i}$ and $\mathrm{j}$ at $\mathrm{t} ; \mathrm{FC}_{\mathrm{ij}, \mathrm{t}-1}$ : a first-order (1-year) lag for fiscal convergence. $\mathrm{DFB}$, takes value 1 when the pair-country of WAEMU presents fiscal balance (including grants) $\geq-3 \%$ of GDP and 0 , otherwise. $\lambda_{i j, t}$ represents bilateral trade costs. (1), (2), and (3), respectively, represent standard model estimates with $D F B_{i j, t} ; D F B_{i j, t}$, and $T I_{i j, t}$. $D F B_{i j, t}, T I_{i j, t}$, and $F C_{i j, t-1}$ are the explanatory variables. (4), (5), and (6), respectively, represent standard model estimates with $S_{i j, t-1}, D F B_{i j, t} ; S_{i j, t-1}, D F B_{i j, t}$, and $T I_{i j, t} . S_{i j, t-1}, D F B_{i j, t}$, and $T I_{i j, t}, F C_{i j, t}$ are the explanatory variables. [.] P-value;(.) robust standard deviations; *** $p<0.01 ; * * p<0.05$; and * $p<0.1$.

Source: Authors' estimates.

\section{Alternative measure of business cycles synchronization: robustness check}

For robustness, we relied on Frankel and Rose (1998) and replaced our dependent variable with the correlation between the cyclical components of output for countries $i$ and $j$. We divided the sample into six equally sized parts ${ }^{13}$ ) (except the last): 1990-94, 1995-99, 2000-04, 2005-09, 
2010-14, and 2015-18. Further, we computed averages of our variables ${ }^{14)}$ in equation (4) over each five-year period (except the last).

Table 7 indicates that the compliance by two countries with the key fiscal convergence criterion $(F B \geq-3 \%$ of the GDP) and the estimated deficit estimated threshold ( $F B \geq$

Table 7. Alternative Measure of Business Cycles Synchronization: Robustness Check

\begin{tabular}{|c|c|c|}
\hline \multicolumn{3}{|c|}{ Business cycles synchronization $\operatorname{Cor}\left(y_{i}^{c}, y_{j}^{c}\right)$} \\
\hline \multicolumn{3}{|c|}{ Panel A: baseline results } \\
\hline \multirow[b]{2}{*}{ Explanatory variables } & \multicolumn{2}{|c|}{ GL2SLS random effects IV regression } \\
\hline & $\begin{array}{l}\text { Compliance with estimated threshold } \\
\qquad F B \geq-3 \% \text { of the GDP }\end{array}$ & $\begin{array}{l}\text { Compliance with estimated threshold } \\
\text { FB } \geq-11.42 \% \text { of the GDP }\end{array}$ \\
\hline$D F B_{i j, t}$ & $\begin{array}{l}0.18^{* *} \\
(0.08)\end{array}$ & $\begin{array}{c}0.42 * * * \\
(0.07)\end{array}$ \\
\hline$T I_{i j, t}$ & $\begin{array}{c}4.11^{* * *} \\
(1.48)\end{array}$ & $\begin{array}{c}5.28^{* * *} \\
(1.46)\end{array}$ \\
\hline$F C_{i j, t-1}$ & $\begin{array}{c}0.11 \\
(0.09)\end{array}$ & $\begin{array}{c}0.06 \\
(0.09)\end{array}$ \\
\hline Observations & 128 & 128 \\
\hline Country pairs & 28 & 28 \\
\hline R-squared & 0.1 & 0.13 \\
\hline Country pair fixed effect & No & No \\
\hline Year fixed effect & Yes & Yes \\
\hline
\end{tabular}

Panel B: first stage of IV estimate

\begin{tabular}{lcc}
\hline \multicolumn{1}{c}{ Explanatory variables } & $T T_{i j, t}$ \\
\hline$\lambda_{i j t}$ & $23.99^{* * *}$ & $23.74^{* * *}$ \\
& $(3.03)$ & $(2.96)$ \\
$D F B_{i j, t}$ & 0.001 & $0.004^{* * *}$ \\
$F C_{i j, t-1}$ & $(0.001)$ & $(0.001)$ \\
& 0.002 & 0.001 \\
Country pair fixed effect & $(0.001)$ & $(0.001)$ \\
Year fixed effect & No & No \\
\hline
\end{tabular}

Note. GDP: gross domestic product; $\mathrm{TI}_{\mathrm{ij}, \mathrm{t}}$ : bilateral trade between countries $\mathrm{i}$ and $\mathrm{j}$ at $\mathrm{t} ; \mathrm{FC}_{\mathrm{ij}, \mathrm{t}}$ : fiscal convergence between countries $\mathrm{i}$ and $\mathrm{j}$ at $\mathrm{t} ; \mathrm{FC}_{\mathrm{ij}, \mathrm{t}-\mathrm{l}}$ : a first-order (1-year) lag for fiscal convergence. DFB, takes value 1 when the pair-country of WAEMU presents fiscal balance (including grants) $\geq-3 \%$ (or $-11.42 \%$ ) of GDP and 0 , otherwise. $\lambda_{i j, t}$ represents bilateral trade costs. We used Hodrick-Prescott (HP) filter with a parameter of 100 (rely on European Commission). Given the small-time dimension $(t=5)$ per country pair, the within estimator is not appropriate. Therefore, relying on Tapsoba (2009), the estimate by the GLS (Generalized least squared) method is retained. $\lambda_{i j, t}$ represents the costs of bilateral trade. (.) robust standard deviations; $* * * p<0.01 ; * * p<0.05$; and $* p<0.1$.

Source: Authors' estimates.

13) We rely on the literature (Baxter \& Kouparitsas, 2005; Calderon et al., 2007; Inklaar et al., 2008), and suppose that the length of the business cycle is between 2 and 8 years. Thus, we arbitrarily chose 5 years, with the exception of the last period (4 years).

14) Concerning the dummy variable $D F B_{i j, t}$, it takes the value 1 if the pair of countries $i, j$ at $t$ comply (on average over the period of 5 years) with the fiscal balance over GDP ratio $\geq$ to the estimated threshold and 0 , othersise. 
$-11,42 \%$ of the GDP) contributed significantly to improve the level of the business cycles synchronization.

Additionally, Table 7 displays that trade integration brings business cycles closer no matter the fiscal convergence threshold. These results complement Tables 5 and 6 (except for the lack of significance for the variable of fiscal convergence). Thus, no matter the measure of business cycles synchronization, the results show that compliance with the thresholds contributes significantly to bringing business cycles closer.

\section{Does the key fiscal convergence criterion need to be adjusted?}

In comparison to the overall fiscal balance convergence criterion in force within the zone (fiscal balance $\geq-3 \%$ of the GDP), there exists a workable margin that can be used to sustain economic growth through expansionist fiscal policies. In the new WAEMU currency, the current key fiscal convergence criterion could be slightly adjusted; adjusting from $-3 \%$ to $-11.42 \%$ of the GDP seems too high, and may have major economic and political consequences (e.g., a debt crisis).

In case of an adjustment, the new standard should reflect the economic realities of the countries within the Union. This is why we prioritized more recent estimates (2006-2018). Such a choice is justified by the fiscal balance behavior change (between 1990-2005 and 2006-2018). Therefore, we repeated our analysis for each sub-period.

Tables 8 and 9 respectively present the linearity tests and results of nonlinear estimates over the two sub-periods.

Table 8. Linearity Test

\begin{tabular}{|c|c|c|c|c|c|c|}
\hline \multirow{2}{*}{ Period } & \multicolumn{2}{|c|}{ Threshold } & \multirow{2}{*}{ RSS } & \multirow{2}{*}{ MSE } & \multirow{2}{*}{ F-Stat } & \multirow{2}{*}{ Prob } \\
\hline & Number & Value & & & & \\
\hline $1990-2005$ & 1 & -11.02 & 4383.24 & 24.898 & 9.24 & 0.043 \\
\hline $2006-2018$ & 1 & -3.97 & 394.17 & 4.332 & 12.07 & 0.020 \\
\hline
\end{tabular}

Note. bootstrap $=300$; RSS: sum of squared residuals; MSE: mean squared errors; F-stat: Fisher's statistical test; Prob: probabilities linked to Fisher stats.

Source: Authors' estimates.

Table 8 shows the existence of a nonlinear relation between the overall fiscal balance and economic growth, characterized by a threshold that varies depending on the sub-period. The estimated threshold is $-11.02 \%$ and $-3.97 \%$ of the GDP over 1990-2005 and 2006-2018, respectively. Thus, since the start of the 2006 public debt relief, the fiscal deficit threshold that should not be exceeded has been reduced from $11.42 \%$ to $3.97 \%$ of the GDP. How do we explain this change in the threshold value? 
First, it is important to note that the estimated thresholds are endogenous and reflect the economic realities of the member countries over the considered analysis period. Thus, before the program, the estimated endogenous threshold was high compared to those estimated in recent literature (Adam \& Bevan, 2005; Amadou \& Kebalo, 2019) because countries, despite high fiscal deficits (Figures 1 and 2), could see their economic growth improve.

However, the positive nonlinear effect on the economic growth of the fiscal balance was small over 1990-2005 (0.097) compared to 2006-2018 (0.186). However, with high fiscal deficits, the Union's debt increased to an average of $108 \%$ of the GDP and became a burden on economic activity (Figure 4), explaining the interest in public debt relief programs.

Table 9 shows that no matter the sub-period when the position of the overall fiscal balance is higher than the estimated threshold, the overall fiscal balance has a positive effect on economic growth. However, whenever the position of the overall fiscal balance was lower than the estimated threshold, the fiscal balance negatively affected economic growth over the first sub-period, but not during the more recent period.

Table 9. Results of the Nonlinear Effect of the Fiscal Balance on Economic Growth

\begin{tabular}{|c|c|c|}
\hline & $\begin{array}{c}\text { Sub-period } 1 \\
1990-2005\end{array}$ & $\begin{array}{c}\text { Sub-period } 2 \\
2006-2018\end{array}$ \\
\hline & Coef. & Coef. \\
\hline$\gamma$ & $-11.02 * *$ & $-3.97 * *$ \\
\hline Constant & $\begin{array}{c}-15.782 * * \\
(-2.30)\end{array}$ & $\begin{array}{r}-10.523 \\
(-1.32)\end{array}$ \\
\hline$F B \geq \gamma$ & $\begin{array}{c}0.097 * * \\
(1.99)\end{array}$ & $\begin{array}{c}0.186^{* *} \\
(2.34)\end{array}$ \\
\hline$F B<\gamma$ & $\begin{array}{c}-0.588^{*} \\
(-1.71)\end{array}$ & $\begin{array}{l}-0.016 \\
(-0.21)\end{array}$ \\
\hline$G C F$ & $\begin{array}{l}0.112 * \\
(1.89)\end{array}$ & $\begin{array}{c}0.323 * * * \\
(4.90)\end{array}$ \\
\hline Open & $\begin{array}{c}0.169 * * \\
(2.12)\end{array}$ & $\begin{array}{l}0.004 \\
(0.14)\end{array}$ \\
\hline$P O P$ & $\begin{array}{l}2.198 \\
(1.31)\end{array}$ & $\begin{array}{l}2.910 \\
(1.11)\end{array}$ \\
\hline$D F B$ & $\begin{array}{c}2.6460 * \\
(1.75)\end{array}$ & $\begin{array}{c}0.107^{*} \\
(1.72)\end{array}$ \\
\hline CI of $\gamma$ & {$[-11.32 ;-10.94]$} & {$[-3.99 ;-3.92]$} \\
\hline F-stat & 3.13 & 5.91 \\
\hline Prob $>$ F & 0.007 & 0.000 \\
\hline Obs & 128 & 104 \\
\hline
\end{tabular}

Note. FB : Overall fiscal balance, including grants (\% of the GDP); GCF: Gross Capital Formation (\% of the GDP); Open: Trade ( $\%$ of the GDP); POP: Total population growth rate $(\%)$. DFB, takes value 1 when the pair-country of WAEMU presents fiscal balance (including grants) $\geq-11.02 \%$ (or $-3.97 \%$ ) of GDP and 0, otherwise. CI: confidence interval. $* * *, * *$, and $*$ for significance at $1 \%, 5 \%$, and $10 \%$, respectively. (.) t-statistics.***, $* *$, and $*$ for significance at $1 \%, 5 \%$, and $10 \%$, respectively.

Source: Authors' estimates. 
Over 2006-2018, the value of the estimated endogenous threshold is reduced because the member countries have understood that by making efforts to contain fiscal deficits and public debt through the mechanism of compliance with the fiscal convergence criteria, economic growth should improve. Over this period, six countries (Benin, Burkina Faso, Côte d'Ivoire, Guinea Bissau, Niger, and Mali) have made tremendous efforts to reduce and contain their fiscal deficits. These operations have increased the economic credibility of the countries in international financial markets (Agbékponou \& Kebalo, 2019).

\section{Economic Implications}

Results show that the estimated threshold $(-11.42 \%$ of the GDP) over the entire period was driven largely by the dynamic of the relation between the fiscal balance and economic growth before the beginning of debt relief programs in 2006. However, with the effective debt reduction of WAEMU countries from 2006, the fiscal deficit threshold that could not be exceed was reduced to $3.97 \%$. This better reflects the Union's recent economic realities.

Moreover, the value of the overall fiscal balance, including grants, criterion $(-3 \%$ of the GDP) within WAEMU, better reflects recent economic realities because the threshold that must be exceeded over the period when the 2015 Convergence Pact was enforced, is $-3.97 \%$ of the GDP, a norm that appears rigorous as well. These are the main reasons that could lead WAEMU countries to retain the convergence criterion in its future Convergence Pact with the new currency.

However, to enable WAEMU countries to enjoy fiscal flexibility or margin to support economic activity through the fiscal policy channel, we suggest that the value of the criterion be adjusted to $-4 \%$ of the GDP. This $-4 \%$ of the GDP proposal presents two major advantages. First, countries will be able to use this slight $1 \%$ of the GDP margin to fund public expenditures, and second, the introduction and compliance with such a standard by the Union would contribute to increasing business cycles synchronizations.

\section{Conclusion}

This paper estimates the fiscal deficit threshold which maximizes economic growth and, when complied with other countries, enables to strengthen the synchronization of business cycles. The analysis includes the Union's eight countries and covers the period from 1990 to 2018. Our results show that the fiscal deficit threshold that should not be exceeded to support growth and which, when complied with, is favorable to the closer alignment of cycles is $11.42 \%$ of the GDP. Consequently, compliance with the convergence criterion limiting the fiscal deficit 
to $3 \%$ of the GDP is pro-growth and increases business cycles synchronization. Besides, results show that the estimated threshold of $-11.42 \%$ of the GDP over the entire period was in large part influenced by the dynamics of the relation between the fiscal balance and economic growth before 2006's debt relief program. However, with the effective debt reduction of countries, the fiscal deficit threshold was reduced to $3.97 \%$ of the GDP. Thus, while the convergence criterion in force seems rigorous given fiscal discipline and could therefore be maintained, it could be adjusted to $4 \%$ of the GDP. Compliance by the countries with this proposed standard could improve the synchronization of business cycles. Moreover, the additional $1 \%$ of the GDP margin could be used to fund development areas.

This study aims to lay the groundwork for new thinking on possible adjustments of criteria within the Growth and Convergence Pact. Although innovative, this study has some limitations. First, an adjustment of the convergence criterion on the overall fiscal balance (including grants) has been proposed without specifying whether the adjustment would be abrupt or gradual. Intuitively, we believe that the adjustment should be gradual. For example, the criterion could be adjusted from $-3 \%$ to $-3.5 \%$ over the first two or three years from the launch of the new currency, and then to $-4 \%$ of the GDP in the subsequent years. This approach aims to observe and analyze the possible impact of this adjustment on countries' debt sustainability, leading to the second limitation. The analysis focused on whether or not the criterion on the fiscal balance could be adjusted based on its impact on economic growth and the business cycles synchronization. Economically, this proposed adjustment would likely affect countries' public debt. This study does not account the impact of such an adjustment on the debt sustainability of the Union countries, especially for countries belonging to a monetary union. Nevertheless, an analysis of the fiscal deficit threshold that must not be exceeded for countries' debt to be sustainable, and compliance for which allows the cycles to be synchronized, would be more interesting.

\section{References}

Adam, C. S., \& Bevan, D. L. (2005). Fiscal deficits and growth in developing countries. Journal of Public Economics, 89(4), 571-597. https://doi.org/10.1016/j.jpubeco.2004.02.006

Agbékponou, M. K., \& Kebalo, L. (2019). Relation Dette-Croissance économique dans la CEDEAO: Analyse à travers une approche non-linéaire. Revue Economique et Monétaire, 26, 9-33.

Agnello, L., Caporale, G. M., \& Sousa, R. M. (2013). Fiscal adjustments and business cycle synchronization. CESifo Working Paper, No. 4505, Center for Economic Studies and ifo Institute (CESifo), Munich.

Agnello, L., Caporale, G. M., \& Sousa, R. M. (2016). How do Fiscal consolidation and fiscal stimuli impact on the synchronization of business cycles? Bulletin of Economic Research, 69(4), 3307-3378. https://doi.org/10.1111/boer.12101

Alagidede, P., Mensah, J. O., \& Ibrahim, M. (2018). Optimal deficit financing in a constrained fiscal 
space in Ghana. African Development Review, 30(3), 291-303. https://doi.org/10.1111/1467-8268.12337

Amadou, A., \& Kebalo, L. (2019). Single currency in ECOWAS: Is the proposed fiscal convergence criterion pro-growth? African Development Review, 31(4), 423-433. https://doi.org/10.1111/1467-8268. 12400

Arellano, M., \& Bond, S. (1991). Some test of specification for panel data: Monte Carlo evidence and an application to employment equations. Review of Economic Studies, 58(2), 277-297. https://doi.org/10. $2307 / 2297968$

Bamba, N. L. (2000). Y a-t-il convergence économique des pays de l'UEMOA. A paraître dans la revue Economie et Gestion du Laboratoire d'Economie Appliquée (LEA). Gabon: Libreville.

Baxter, M., \& King, R. G. (1999). Measuring business cycles: approximate band-pass filters for economic time series. Review of Economics and Statistics, 81(4), 575-593. https://doi.org/10.1162/003465399558454

Baxter, M., \& Kouparitsas, M. A. (2005). Determinants of business cycle co-movement: A robust analysis. Journal of Monetary Economics, 52(1), 113-157. https://doi.org/10.1016/j.jmoneco.2004.08.002

Blundell, R., \& Bond, S. (1998). Initial conditions and moments restrictions in dynamic panel data models. Journal of Econometrics, 87, 11-143. https://doi.org/10.1016/S0304-4076(98)00009-8

Buti, M., Brunila, A., \& Franco, D. (2001). The stability and growth pact: the architecture of fiscal policy in EMU. Springer.

Calderon, C., Chong, A., \& Stein, E. (2007). Trade intensity and business cycle synchronization: Are developing countries any different? Journal of International Economics, 71(1), 2-21. https://doi.org/10. 1016/j.jinteco.2006.06.001

Canova, F. (1998). Detrending and business cycles facts. Journal of Monetary Economics, 41, 475-512. https://doi.org/10.1016/S0304-3932(98)00006-3

Canova, F. (1999). Does detrending matter for the determination of the reference cycle and the selection of turning points? Economic Journal, 109, 126-150. https://doi.org/10.1111/1468-0297.00395

Canry, N., Fouquau, J., \& Lechevalier, S. (2007). Price dynamics in japan (1981-2001): A structural analysis of mechanisms in the goods and labor markets. Discussion Paper, Series A. The Institute of Economic Research Hitotsubashi University Kunitachi. p. 493.

Cesa-Bianchi, A., Imbs, J., \& Saleheen, J. (2019). Finance and synchronization. Journal of International Economics, 116, 74-87. https://doi.org/10.1016/j.jinteco.2018.08.007

Cooper, R. (1974). Worldwide vs. regional integration: Is there an optimal size of the integrated area? [Technical Report]. Center Discussion Paper.

Couchoro, M. K., Dout, H., Kebalo, L., \& Zouri, S. (2022). Intégration économique régionale et inégalités de revenu dans la CEDEAO: une nouvelle preuve empirique. Documents de Recherche de l'OFE (DROFE) No. 26, Observatoire de la Francophonie Économique

Diarra, S. (2016) Analyse rétrospective du respect des nouveaux critères de convergence de l'UEMOA. Revue d'économie du developpement, 24(1), 79-98. https://doi.org/10.3917/edd.301.0079

Diop, L. (2002). Convergence nominale et Convergence réelle: Une application des concepts de $\delta$ -convergence et de $\beta$-convergence aux économies de la CEDEAO. UEMOA: Note d'Informations Statistiques de la BCEAO, p. 531.

Dout, H., \& Kebalo, L. (2021) Trade intensity, fiscal integration and income inequality in ECOWAS. 
Statistics, Politics and Policy, 12(2), 375-394. https://doi.org/10.1515/spp-2021-0008

Egger, P., Nigai, S., \& Strecker, N. (2019). The taxing deed of globalization. American Economic Review, 109(2), 353-390. https://doi.org/10.1515/spp-2021-0008

Fouquau, J. (2008). Modèles à changements de régimes et données de panel: de la non-linéarité à l'hétérogénéité (Doctoral dissertation). Orléans.

Frankel, J. A., \& Rose, A. K. (1998). The endogeneity of the optimum currency area criteria. Economic Journal, 108(449), 1009-1025. https://doi.org/10.1111/1468-0297.00327

Gammadigbe, V., Issoufou, I., Sembene, D., \& Tapsoba, SJ-A. (2018). Convergence budgétaire en Afrique: quel rôle pour les communautés économiques régionales? Revue d'Economie du Développement, 26(3), 5-31. https://doi.org/10.3917/edd.323.0005

Giannone, D., Lenza, M., \& Reichlin, L. (2010). Business cycles in the Euro area. National Bureau of Economic Research, Inc, 141-167.Hansen, B. E. (1999). Threshold effects in non-dynamic panels: Estimation, testing, and inference. Journal of Econometrics, 93(2), 345-368. https://doi.org/10.1016/S0 304-4076(99)00025-1

Hodrick, R. J., \& Prescott, E. C. (1997). Postwar US business cycles: An empirical investigation. Journal of Money, Credit, and Banking, 29(1), 1-16.

Hurlin, C. (2005). Network effects of the productivity of infrastructure in developing countries. Policy Research Working Paper, 3808. World Bank.

Im, K. S., Pesaran, M. H., \& Shin, Y. (2003). Testing for unit roots in heterogeneous panels. Journal of Econometrics, 115(1), 53-74.

International Myeloma Foundation. (2013). Dancing together? spillovers, common shocks, and the role of financial and trade linkages. Washington: World Economic Outlook. International Monetary Fund.

Inklaar, R., Jong-A-Pin, R., \& de Haan, J. (2008). Trade and Business Cycle Synchronization in OECD countries A Re-examination. European Economic Review, 52(4), 646-666. https://doi.org/10.1016/j.eur oecorev.2007.05.003

Kalemli-Ozcan, S., Papaioannou, E., \& Perri, F. (2013). Financial regulation, financial globalization, and the synchronization of economic activity. Journal of Finance, 68(3), 1179-1228. https://doi.org/10.1111 /jofi. 12025

Kebalo, L., \& Zouri, S. (2021). Réforme du dispositif de surveillance multilatérale de l'UEMOA: faut-il ajuster le critère de convergence relatif au solde budgétaire? Documents de Recherche de l'OFE (DROFE) No. 19, Observatoire de la Francophonie Économique.

Kindleberger, C. (1986). International public goods without international government. American Economic Review, 76(1), 1-13.

Levin, A., Lin, C., \& Chu, C. (2002). Unit root test in panel data: Asymptotic and finite sample properties. Journal of Econometrics, 108(1), 1-24. https://doi.org/10.1016/S0304-4076(01)00098-7

Manasse, P. (2015). Deficit limits, budget rules, and fiscal policy. IMF Working Paper, 05/120.

Mpatswe, M. G. K., Tapsoba, M. S. J. A., \& York, M. R. C. (2011). The cyclicality of fiscal policies in the CEMAC region. International Monetary Fund.

Ndoricimpa, A. (2017). Threshold effects of debt on economic growth in Africa. African Development Review, 29(3), 471-484. https://doi.org/10.1111/1467-8268.12282 
Rapport annuel 2019 de la BCEAO. https:/www.bceao.int/fr/publications/rapport-annuel-de-la-bceao-2019

Ravn, M. O., \& Uhlig, H. (2002). On adjusting the Hodrick-Prescott filter for the frequency of observations. Review of Economics and Statistics, 84(2), 371-376. https://doi.org/10.1162/003465302317411604

Reinhart, C., Kaminsky, G., \& Végh, C. (2004). When it rains It pours: Procyclical capital flows and macroeconomic policies. NBER Macroeconomic Annual, 19, 11-53.

Riezman, R. G., Whalley, J., \& Zhang, S. (2013). Metrics capturing the degree to which individual economies are globalized. Applied Economics, 45(36), 5046-5061. https://doi.org/10.1080/00036846.2013.815312

Samimi, P., Lim, G. C., \& Buang A.A. (2011). Globalization measurement: Notes on common globalization indexes. Journal of Knowledge Management, 1(7), 1-20.

Savvides, A., \& Stengos T. (2000). Income inequality and economic development: Evidence from the threshold regression model. Economics Letters, 69, 207-212. https://doi.org/10.1016/S0165-1765(00)00 293-7

Tapsoba, SJ-A. (2009). Hétérogénéité des chocs et viabilité des unions monétaires en Afrique de l'Ouest. Revue Economique et Monétaire, 5, 38-63.

Zahonogo, P. (2017). Trade and economic growth in developing countries: Evidence from Sub-Saharan Africa. Journal of African Trade, 3, 41-56. https://doi.org/10.1016/j.joat.2017.02.001

Zouri, S. (2020). Business cycles, bilateral trade and financial integration: Evidence from Economic Community of West African States (ECOWAS). International Economics, 163, 25-43. https://doi.org/10.1016/j.inte co.2020.04.001 